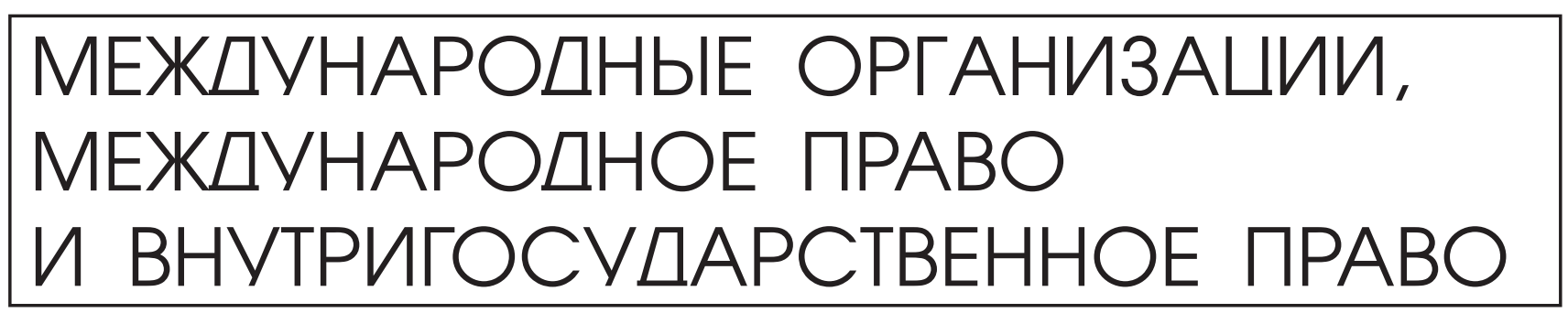

Смирнова Е.С.

\title{
НЕКОТОРЫЕ ВОПРОСЫ ИМПЛЕМЕНТАЦИИ МЕЖДУНАРОДНЫХ НОРМ О ЗАЩИТЕ ПРАВ ЧЕЛОВЕКА В СФЕРЕ ПРОИЗВОДСТВА И ПОТРЕБЛЕНИЯ УСЛУГ: ИСТОРИЯ И СОВРЕМЕННОСТЬ
}

Аннотация. Проблемы имплементачии норм международного права в сфере защиты прав человека-потребителя имеют большое значение в мире в условиях высокого уровня экономического сотрудничества. Показаны перспективы взаимодействия международных организаций, государств и регионов в этой сфере. Россия разрабатывает законодательство в соответствии с нормами международного права. Страны Евразийского региона имеет перспективы решения подобных вопросов консолидированными силами. В этом залог успешного решения проблем.

Ключевые слова: Международное право, безопасность, государство, население, экономика, услуги, товары, потребление, товарооборот, иень

овременный этап развития мировой экономики связан с активизацией глобальных процессов, в том числе в сфере услуг, что несет в себе соответствующие риски и угрозы интересам всех участников потребительского рынка'. Люди хотят жить лучше, пользоваться комфортом и всеми благами, представленными поставщиками товаров и услуг. При этом в настоящее время во всем мире вопросы безопасности товаров (услуг) приобретают первостепенное значение. Поэтому государственные органы, а также общественные организации, которые в силу своей профессиональной деятельности стоят на страже прав и интересов граждан - потребителей, приоритетом в своей работе определяют совершенствование существующих механизмов государственной и общественной защиты соответствующих прав человека как на стадии досудебного урегулирования потребительских споров, так и в рамках судебной защиты этих прав.

\footnotetext{
${ }^{1}$ См.: Медведев Д.А. Новый Гражданский Кодекс РФ: вопросы кодификации /Кодификация российского частного права. Под. ред. Д.А. Медведева. М., 2008.
}

Торговля всегда была ключевым фактором экономического роста и повышения уровня жизни населения ${ }^{2}$ В целом же, необходимо напомнить, что потребительская политика в мире имеет относительно недавнее происхождение. Она появилась в США как ответ на злоупотребления участников рыночных отношений (производителей и продавцов), в случае невозможности неподготовленному человеку осуществить адекватный выбор товара и защитить свои права в ситуации их нарушения. В 60-80 годах XIX века в США прокатились первые компании в целях защиты интересов потребителей от железнодорожных компаний, завышавших цены на перевозку пассажиров и грузов. В результате государство поставило под свой контроль железнодорожные тарифы и создало специальный орган сенатскую Комиссию по торговле между штатами. В 1899 году в США была создана Национальная лига потребителей, которая принимала активное участие в компании по защите прав потребителей. В 1935 году создается Союз потребителей, кото-

${ }^{2}$ См.: King $M$. Do we need an international monetary system?/ Mode of access : http / www. Centpapiers. Com. 1\% E2\% 80\% 36275 . 
рый в наши дни насчитывает в своих рядах свыше 5 миллионов человек. Следует указать, что именно деятели этого Союза первыми призвали к бойкоту товаров из фашистской Германии в 30 -е годы.

В 50-е годы XX века происходит заметный рост активности потребительских организаций. В этот же период в США появились еще несколько общественных организаций, действующих в этом направлении: Центр за безопасность автомобиля, Исследовательская группа по здравоохранению, Центр исследования и действия по телекоммуникациям и другие.

Летом 1962 года по указанию Дж. Кеннеди был учрежден Консультативный совет по делам потребителей, преобразованный в 1971 году в Управление по делам потребителей. В некоторых комитетах Конгресса США (по торговле, банкам и финансам, науке и транспорту и другим) и в настоящее время функционируют подкомитеты по проблемам потребителей, которые проводятся с участием заинтересованных лиц и представителей потребительских организаций. Комиссия по безопасности товаров США имеет право потребовать от промышленников или продавцов исправления, замены, изъятия товара, если он не соответствует утвержденным правилам и стандартам.

Безусловно, следовало бы сказать, что США избежали революций и войн, которые в XX веке пережили Европа и Россия. В силу этого они и могут позволить себе на самом высоком государственном уровне уделять так много внимания проблемам защиты прав потребителей. Но причина не только в этом. Достаточно высокая стабильность политики, прагматизм и упорная защита государственных интересов служат той основой, на которой выстраивается вся система государственной социальной политики. Этот опыт стал примером для многих стран мира. В дальнейшем страны Европейского Экономического Сообщества стали развивать политику в сфере защиты прав потребителей в аналогичном направлении. В настоящее время успех в этом деле приобрели коммунитарные структуры Европейского союза. Таким образом, можно сделать вывод, что регулирование отношений, связанных с обслуживанием населения, также обязывает государственные органы и общественные организации изучать опыт развитых в экономическом плане стран, где борьба между интересами общества и капитала уравновеши- валась разумными действиями государственной власти по недопущению кризисных ситуаций

Обращаясь к универсальным источникам, регулирующим защиту прав потребителей, следует назвать в качестве одного из главных Устав ООН, так как на его основе складываются все отношения в сфере защиты прав человека. Такой документ как Международная конвенция по защите социальных, экономических и культурных прав граждан 1966года, и в наши дни является правовым источником, не теряющим своей актуальности. Нормы Экономического и Социального Совета (ЭКОСОС), выполняющего функции, изложенные в гл.ІХ Устава ООН «Международное экономическое и социальное сотрудничество», имеют особое значение для рассматриваемой темы-защиты прав потребителей. ЭКОСОС предпринимает исследования и составляет доклады по международным вопросам в таких областях как экономика, социальная сфера, образование, здравоохранение. По каждому из этих вопросов организация может представлять свои рекомендации членам $\mathrm{OOH}$ и другим учреждениям.

Среди специализированных организаций $\mathrm{OOH}$, также имеющих непосредственное отношение к проблеме защиты прав потребителей, следует назвать Продовольственную и сельскохозяйственную Организацию Объединенных Наций (ПРООН), Организацию Объединенных Наций по промышленному развитию (ООНПР), Всемирную Организацию здравоохранения (ВОЗ), а также Международную организацию труда(МОТ). Каждая из этих организаций выполняет задачи, которые в определенной степени имеют отношение к вопросам защиты прав потребителей, безопасности продуктов питания, услуг и регулированию трудовых отношений.

В одной из Резолюций, принятых Генеральной Ассамблеей $\mathrm{OOH}$ в 1964 году4, также утверждается, что международная торговля может быть одной из движущих сил развития и поступательного экономического роста. При этом обращается особое внимание на необходимость полного

\footnotetext{
${ }^{3}$ См.: Вавилин Е.В., Челышев М.Ю. О концепции гражданско-правовой политики /Гражданское право. 2012.№1.С.14.

${ }^{4}$ По докладу Второго комитета А: 343 Add.164/142- ч.2 «Международная торговля и развитие»/Цитируем по: Журнал международного частного права. 2011.№1.
} 
задействования потенциала международной торговли, подчеркивается важность поддержки универсальной, основанной на праве, открытой, недискриминационной и справедливой многосторонней торговой системы, способствующей росту, устойчивому развитию и созданию рабочих мест, особенно в развивающихся странах ${ }^{5}$.

При рассмотрении проблем, связанных с защитой прав человека-потребителя следует указать на такой документ как Руководящие принципы ООН для защиты прав потребителей от 9 апреля 1985 года, где отмечается: «Политика правительств должна быть направлена на предоставление потребителям возможности максимально выгодно использовать свои экономические средства. Она также должна быть направлена на обеспечение удовлетворительных технических и эксплуатационных характеристик, надлежащих методов распределения, добросовестной деловой практики, информативного маркетинга и эффективной защиты против практики, которая может отрицательным образом затронуть экономические интересы потребителей и осуществление выбора при покупке» ${ }^{6}$ (п.13). Написанные в период современного (нового) международно-правового нормотворчества, заложенного Уставом $\mathrm{OOH}^{7}$, эти Принципы стали той основой, на которой должна формироваться вся последующая правовая база как международного права, так и национального права отдельных государств, направленная на защиту прав потребителей.

Организация Объединенных Наций продолжает работу в этом направлении. Так, в 2001 году по решению Четвертой Конференции ООН прошла встреча экспертов по вопросам потребительской политики, по итогам которой были приняты руководящие принципы для защиты интересов потребителей с учетом «Руководящих принципов для защиты интересов потребителей» 1985 года.

Однако дальнейшая работа ООН по реализации «Руководящих принципов для защиты прав

\footnotetext{
${ }^{5}$ См. подробнее: Журнал международного частного права. 2011.№1.

${ }^{6}$ См.: Указ Президента РФ от 18 июля 2008г. №1108 «О совершенствовании Гражданского Кодекса РФ»/Российская газета. 23 июля 2008г.№155.С. 19.

${ }^{7}$ См. подробнее: Лукашук И.И. Международное право. Общая часть. Учебник. М., 1996. С.64.
}

потребителей» в настоящее время приостановлена по причине экономического кризиса. В то же время, процессы, происходящие в мировой экономике, диктуют необходимость разработки и признания международным Сообществом Международного Кодекса защиты прав потребителей, как единого документа в области защиты прав и интересов потребителей. Значение Руководящих принципов ООН для развивающихся стран и стран с переходной экономикой было конкретизировано на совещании экспертов ЮНКТАД по вопросу: «Интересы потребителей, конкурентоспособность, конкуренция и развитие», состоявшемся в Женеве в октябре 2001 года. Следует возлагать надежды на последующее развитие подобных документов, несмотря на сложности финансирования и нежелание некоторых стран вкладывать денежные средства в эту стратегию развития мировой экономики.

Отмечая деятельность специализированных организаций, следует назвать, основанную в 1960 году Международную организацию союзов потребителей (IOCU)- International organization of consumers unions. Данная организация создавалась с целью объединения национальных союзов потребителей всего мира. В 1995 году Международная организация союзов потребителей была переименована в Международную ассоциацию потребителей (МАП) -Consumers International (CI), штаб-квартира которой находится в Лондоне, являющуюся независимой, некоммерческой организацией, финансируемой в основном за счет внесения взносов организациями-членами и различными фондами 8 .

Диапазон деятельности Международной ассоциации потребителей довольно широкий, она помогает национальным ассоциациям потреби-

\footnotetext{
${ }^{8}$ В Международную ассоциацию потребителей входят организации таких стран как Россия, Франция, Германия, Канада, Бразилия, Швеция, Чехия, Дания, Италия, Норвегия, Румыния, Словения и многих других. В своей деятельности Международная ассоциация потребителей, как и национальные организации потребителей, исходит из Руководящих принципов для защиты прав потребителей, принятых Генеральной Ассамблеей ООН 9 апреля 1985 г. (резолюция № 39/248), которые определяют международные основы политики в сфере защиты интересов и прав потребителей /См.: Consumers International/Сайт Международной ассоциации потребителей: http://www.consumersintemationaI.org/about_CI/ default.asp?regionid $=135$
} 
телей многих стран мира; координирует их деятельность по защите прав и интересов потребителей; способствует развитию потребительского движения во всем мире; представляет интересы потребителя на международном уровне; оказывает влияние на принятие решений крупными межправительственными организациями, которые затрагивают права и интересы потребителей; издает ежеквартально журнал «Consumer-XXI», в котором анализируется деятельность мирового потребительского движения.

В то же время МАП не в состоянии решить многие проблемы защиты потребителей в развивающихся странах, её решения носят рекомендательный характер и не обязательны к исполнению. Существенным недостатком является то, что в ряде развивающихся стран отсутствуют даже формальные системы защиты потребителя, и нет правовой базы для её формирования ${ }^{9}$ Возможное сокращение численности организации связано с усилением процессов экономической активности ТНК и неизбежно с изменением позиции ООН по проблемам защиты потребителя, которая «законсервировала» это направление своей деятельности ${ }^{10}$. Как отмечают аналитики, в 2008-2009 годах наблюдался резкий спад мировой торговли ${ }^{11}$, что демонстрирует внутреннюю связь между активной деятельностью международных организаций и повышением уровня жизни населения.

Следует также назвать региональные международно-правовые нормы, которые имеют непосредственное отношение к проблеме защиты прав потребителей в России. Прежде всего - это нормы Совета Европы. Ратифицированная Россией Конвенция Совета Европы о правах и основных свободах человека 1995 года, оказывает значительное влияние на российскую правовую систему. Европейская социальная хартия по существу является составной частью права Российской Федерации, и обязывает законода-

\footnotetext{
${ }^{9}$ См.: Consumers International/Сайт Международной ассоциации потребителей:http://www.consumersinternational.org/ about_CI/default.asp?regionJd $=135$

${ }^{10}$ См.: Consumers International/ См.: Сайт Международной ассоциации потребителей:http://www.consumersintemationaI. org/about_CI/default.asp?regionid $=135$

${ }^{11}$ См.: Hugon Ph. Apres la crice, un nouveau paradigm du development /Problems econ. P. 2011. №3011. P.46.
}

телей разрабатывать нормы права(в том числе и социальной защиты населения) в соответствии с европейскими стандартами.

Что же касается норм европейского права (ЕС), то следует отметить, что вплоть до 1973 года на уровне стран - участников Европейского Экономического Сообщества (ЕЭС) не предпринимались какие-либо попытки рассматривать специально вопрос, связанный с потребительской политикой и созданием правовой базы с целью защиты интересов потребителей. В 1973 году в рамках Комиссии Сообществ создается специальный орган Консультативный комитет по защите прав потребителей. В Европейском Экономическом Сообществе с принятием первой программы по защите прав потребителей в 1975 г. официально стала проводиться политика по защите прав этой категории населения, появились общие программные документы органов ЕЭС в данной сфере, а затем и нормативные акты в форме директив Совета Сообществ. Советом Сообществ были приняты нормативные акты о безопасности и качестве текстильных, продовольственных товаров, об опасных для жизни и здоровья веществах, способствовавшие созданию цивилизованного рынка товаров, работ и услуг.

В первой программе ЕЭС по защите прав потребителей и информационной политике 1975 года провозглашалось, что Сообщество имеет намерение улучшить качество жизни народов Сообщества. В Программе утверждались пять основных прав потребителя: право на охрану жизни, здоровья и безопасность товаров и услуг; право на защиту экономических интересов; право на возмещение причиненного ущерба; право на информацию и просвещение; право на представительство (право быть услышанным).

Вторая Программа ЕЭС по защите прав потребителей и информационной политике, как юридически значимый документ, была принята 19 мая 1981 года. Эта Программа обеспечивала преемственность в решении задач, определенных в первой Программе и определяла дальнейшую политику Сообщества в данном направлении. Гармонизация норм подразумевала установление определенных параметров качества, извещение 
о наличии в государстве - члене ЕЭС специальных норм анализа и тестирования, маркировки и стандартов безопасности. В 1986 году одобряется новая Программа и создается график принятия нормативных актов по защите прав потребителей.

В развитие этих правовых норм Совет Сообществ 9 ноября 1989 года одобрил постановление «О дальнейших приоритетных направлениях политики защиты потребителей». Был разработан трехлетний план действий в области политики по защите прав потребителей в ЕЭС (1990-1993 гг.). Следует указать, что разработка общеевропейского кодекса частного права в соответствии с Резолюцией Европейского парламента от 26 мая 1989г. стала большим событием для ученых и практиков, занимающимся проблемами защиты прав человека-потребителя ${ }^{12}$.

Право Европейского союза, регулирующее с 1993 года отношения между странами наиболее развитыми в экономическом отношении, также представляет не меньший интерес. Например, Регламент Европейского парламента и Совета (ЕC) № 2006/2004 от 27 октября 2004 г. «О сотрудничестве между национальными органами, ответственными за реализацию законодательства о защите потребителей» (Регламент о сотрудничестве по защите потребителей - OJ 2004 L 364/1) объединяет многие документы права ЕС в этой сфере, вводя их содержание в круг вопросов сотрудничества и взаимопомощи между соответствующими структурами, занимающимися вопросами защиты прав потребителей.

В марте 2010 года в ЕС была принята новая европейская стратегия экономического развития «Европа -2010: Стратегия разумного, устойчивого и интегрирующего роста». Стратегия явилась своего рода продолжением Лиссабонской стратегии на 2000-2010 годы, которая потерпела неудачу из-за отсутствия координации между странами ЕС и кризисных явлений в предшествующие годы. В этом документе также уделяется много внимания вопросам защиты прав человека-потребителя,

\footnotetext{
${ }^{12}$ См. подробнее: Keirse A.L.M. European impact on contract law A perspective on the interlinked contributions of legal scholars. Legislators and courts to the Europeanization of counteract law /Utrecht law rev. Utrecht. 2011.V.7.N.1.P.46.
}

проблеме повышения уровня жизни граждан Европейского союза ${ }^{13}$.

Таким образом, политика и практика ЕC в сфере защиты прав потребителей имеют определенный историко-правовой опыт. Создана нормативная база, выражающаяся в программных документах, которые отражают основополагающие принципы политики защиты интересов потребителей на уровне стран-участников ЕС. После создания ЕС в 1992 году защита прав потребителей стала политикой всего сообщества и была введена в ранг первостепенных задач.

В дополнение к разработке законодательной программы по защите прав потребителей, ЕС принял меры по обеспечению соблюдения законов на местном уровне и коммунитарном ЕС. Это обеспечило развитие национальных организаций по защите прав потребителей и пяти ведущих организаций на уровне EC: Европейской Организации Потребителей, Конфедерации Семейных Организаций ЕC, Европейском Сообществе Потребительских Кооперативов, Европейской Конфедерации Профсоюзов, Европейском Межрегиональном Институте по Делам Потребителей.

В настоящее время экономический и финансовый кризис в ряде стран ЕС привел к сокращению ассигнований на развитие этого направления сотрудничества. Появились и практические последствия режима жесткой экономии. Отмечается такая негативная тенденция, появившаяся в последние годы, как неравенство в поставках продуктов в странах Центральной Европы и во Франции и Германии. В последние годы Словацкая ассоциация по защите прав потребителей пришла к выводу — в странах Восточной Европы продаются продукты более низкого качества, чем в Западной Европе, хотя продаются под одними и теми же торговыми марками ${ }^{14}$. Таким образом, продукты

\footnotetext{
${ }^{13}$ См. подробнее: Europe -2010 La strategie europeenne pour une croissance intelligente durable et inclusive / Mode of access: http:// www. Un. Org/apps/ newsFr/ storyF.asp? NewsID $=22885 \& \mathrm{Cr}=$ faim $\& \mathrm{Crl}=$.

${ }^{14}$ Отличие отмечают также и латвийские покупатели. Это относится как к стиральным порошкам, так к зубным пастам и сладостям. Например, йогурт одного и того же бренда, произведенный в Германии для западного рынка и произведенный в Польше для восточноевропейского отличается по консистенции - в немецком выше содержание молока и
} 
завоевавшие рынок, не обязательно являются лучшими ${ }^{15}$. И все же, несмотря на имеющееся отрицательные примеры, правовой опыт стран ЕС прекрасно показывает пример сплоченности в решении проблем, связанных с защитой прав потребителей. Это может служить ориентиром для России при выработке собственной региональной экономической политики.

Помимо Европейского союза на политической карте Европы активно действует в направлении укрепления социальной сплоченности Совет Европы. Проблематика социальной сплоченности, как она была сформулирована на второй встрече государств-членов Совета Европы в 1997 году, относится к приоритетным сферам деятельности организации на ближайшие годы. Был создан новый орган - Европейский комитет по вопросам социальной сплоченности, который занимается разработкой стратегии в этом направлении. Основываясь на результатах предыдущего проекта под названием «Человеческое достоинство и социальное отчуждение», данная стратегия направлена главным образом на реализацию прав в социальной сфере для всех граждан, а также на поддержку семей и детей. Отдел по вопросам развития социальной сплоченности, который был создан после принятия на втором саммите стран-участников Совета Европы плана действий, занимается исследовательской и аналитической работой. В его компетенцию входит разработка общей стратегии действий Организации в этой области, а также реализация проектов в ряде государств (программа ADAKS). Отдел отвечает за выполнение совместной программы между Советом Европы и Банком развития Совета Европы ${ }^{16}$ и устанавливает страте-

ягод, в польском - содержание синтетических Е-добавок. Приходится ждать более весомых исследований в этой сфере и, возможно, судебных прецедентов.

${ }^{15}$ См.: Demeulemeester J. L., Diebolt Cl. Renouveler la science economique neo -classique ?Prendre lhistorisite au serieux/ Assotiation francaise de cliometrie Worcing papers. 2011. N.3 P.15.

${ }^{16}$ Банк развития был создан в 1956 году согласно частичному соглашению Совета Европы, и в настоящее время в него входят 35 стран-членов. Его главной целью является оказание финансовой помощи государствам-членам в решении социальных проблем, которые могут возникать в результате присутствия беженцев, перемещённых лиц или лиц, пострадавших от природных или экологических бедствий. гически важные связи с другими национальными и международными партнерами.

Следует также указать и на недостатки, содержащиеся в праве ЕС в области защиты прав потребителей. Имеется мнение о необходимости признания права потребителей самостоятельным институтом ЕС. Целесообразно объединить воедино разрозненные директивы по отдельным вопросам договоров с участием потребителей и отдельным видам договоров по торговле вне коммерческого предприятия продавца - дистанционной купле-продаже потребительских товаров. Эксперты полагают, что при реализации «товаров на ходу» воля покупателя не реализуется в полной мере, товар приобретается «по умолчанию», что не способствует условиям действительности договора - проявлению воли покупателя в полном объеме ${ }^{17}$.

Как отмечалось, правовая инициатива стран ЕС имеет своим результатом выработку нескольких международных конвенций, направленных на укрепление сотрудничества государств в социальной области. Европейские конвенции, направленные на защиту социальных прав должны быть изучаемы в России в силу вхождения нашего государства в Совет Европы с 1996 года. Этот факт обязывает учитывать правовые нормы Совета Европы при разработке правовой базы России применительно и к такой ответственной отрасли как защита прав потребителей.

Европейская социальная хартия, вместе с ее протоколами и пересмотренным текстом Хартии, гарантируют целый ряд основополагающих социальных прав (см. раздел «Права человека: их защита, информация о правах и предупреждение их нарушения»). Европейский кодекс социального обеспечения и протокол к нему гарантируют минимальный уровень социальной защиты, включая медицинское обслуживание, выплату пособий по болезни и временной нетрудоспособности в связи с получением производственных травм, пособий по случаю рождения ребёнка, по безработице, инвалидности и в случае потери кормильца, а также детские пособия и пенсии. Пересмотренный и

\footnotetext{
${ }^{17}$ Cм.: Wagner G. Functions and principles in light of the proposal for a directive on consumer right / Erasmus law rev. Rotterdam 2010. V.3. N.1.,P.47-70.
} 
дополненный вариант Кодекса 1990 года учитывает последние изменения в законодательстве, касающиеся социального обеспечения в странах-членах и закрепляет расширение норм социальной защиты.

Можно сделать вывод, что социальная защита за рубежом в целом, имеет большую и разветвленную систему, направленную на адаптацию трудящегося к меняющимся условиям рынка и на его защиту в рамках государства и ЕС в целом. Переезд работающих лиц и их семей из одной страны в другую, их адаптация в странах пребывания без потери культурной самобытности, их правовая и социальная защита, оказание услуг в целом, обеспечиваются, кроме вышеуказанной Европейской конвенцией по социальному обеспечению, следующими соглашениями:

1) Европейской конвенцией по социальной и медицинской помощи, содержащей положения о равном отношении к людям. Каждое подписавшее конвенцию государство взяло на себя обязательство обеспечить граждан другого государства, являющегося участником данной конвенции, которые находятся на законных основаниях на его территории, такой же социальной и медицинской помощью, как и своих собственных граждан;

2) Европейской конвенцией о правовом статусе рабочих мигрантов, которая устанавливает принцип равенства правового положения местных рабочих и мигрантов, гарантирует право семей на воссоединение. Контроль за выполнением ее положений осуществляет консультативный комитет.

Названные две конвенции Совета Европы позволяют составить общую характеристику того объема документов, которые разработаны с целью гармонизации правовых систем стран EC в плане социальной защиты населения. Они дополняют нормы права ЕС, укрепляют правовую составляющую этого регионального союза, позволяют представить картину движения к прогрессу в экономической сфере, несмотря на экономические кризисы.

Одной из самых эффективных мер административного характера в этом направлении следует назвать учреждение в рамках Совета Европы в Лиссабоне в 1990 году Европейского центра глобальной взаимозависимости и солидарности (центр Север-Юг). Основными областями деятельности этой организации являются образование, информация и коммуникация. Центр проводит коллоквиумы, форумы, семинары, публикует различную информацию, издает на ежемесячной основе газету «Взаимозависимость», где пропагандируется лозунг: проблемы защиты человекапотребителя являются первостепенными.

Помимо отмеченного, Совет Европы предпринимает успешные шаги по улучшению уровня защиты здоровья потребителей. Обеспечивая научную и методологическую базу для национальных законодательных реформ и директив развития отдельных территорий, имеющих прямое или косвенное воздействие на продукты потребления (а также пестициды, фармацевтические и косметические продукты), Совет Европы тем самым способствует унификации законодательств, правил применения и практики использования, контроля качества, эффективности и безопасности продуктов, а также правил безопасности при применении токсических или ядовитых веществ. Таков экскурс в историю развития институтов солидарности Европы в деле защиты прав человека- потребителя. Можно критически отнестись к такой формулировке, но за ней скрыта большая забота о людях, проживающих в Европе. Пример подобного юридического сотрудничества должен быть изучен, и последовательно претворен в пределах Содружества Независимых Государств.

Переходя к анализу страновой политики по развитию движения за защиту прав потребителей, нужно еще раз подчеркнуть первостепенное внимание к этой проблеме европейских стран. Отмечая успехи конкретной страны, можно привести пример Швеции, которая предприняла многие действия в этом направлении. В этом государстве с 1971 года учреждена должность Омбудсмена по защите прав потребителей. Он назначается на конкретный срок законодательной властью государства. Краткий аналитический экскурс в развитие проблем защиты прав потребителей (консюмеризма ${ }^{18}$ ) показывает, что имеет смысл калькирования подобных институтов в других странах во избежание социальных потрясений.

\footnotetext{
${ }^{18}$ Термин «консьюмеризм» означает «движение в защиту прав потребителей». См.: Wagner G. Functions and principles in light of the proposal for a directive on consumer right / Erasmus law rev. Rotterdam 2010. V.3. N.1.,P.47-70.
} 
Подтверждением этого тезиса служит факт того, что именно в последние годы в странах Запада либеральное направление в экономической науке сменилось на более консервативное. Тенденцией является стремление критически осмыслить историю экономики. Например, сотрудница Счетной Палаты Франции В. Шароль, опираясь на работу А.Смита «Исследование о природе и причинах богатства народов», при изучении проблемы соотношения теорий либерализма и капитализма, приходит к выводу, об убежденности А.Смита в необходимости присутствия государства в процессе развития торговли. Делается весьма значимый вывод о том, что капитализм не является единственным способом функционирования рыночной экономики ${ }^{19}$. Таким образом, именно уровень защиты прав человека-потребителя может служить основанием для более серьезных политических обобщений.

Рассматривая проблемы защиты прав потребителей в Российской Федерации и регионе Содружества Независимых Государств, можно отметить перспективность этого направления деятельности. Только в 80-х годах XX века в бывшем СССР стали зарождаться общества, клубы, ассоциации по защите прав потребителей. В 1987 1988 годы эти общественные организации объединились в Федерацию обществ потребителей, президентом которой был А. Б. Собчак.

К началу 1992 года российская Федерация обществ потребителей уже входит в Международную конфедерацию обществ потребителей (КонфОП), объединяющую аналогичные структуры бывших союзных республик СССР - России, Беларуси, Украины, Казахстана, Туркменистана, Таджикистана и других стран ${ }^{20}$. В свою очередь

\footnotetext{
${ }^{19}$ Cм.: Charolles V. Le capitalism est-il liberal ? /Debat. P.2010. N.161. P.88-103.

${ }^{20}$ Общественные организации по защите прав потребителей тесно сотрудничают с другими объединениями, например, с советами ветеранов Великой Отечественной войны, с организациями инвалидов, клубами автолюбителей, региональными центрами стандартизации, метрологии и сертификации, независимыми экспертизами, государственными органами по защите прав потребителей. Одной из основных целей КонфОП является предоставление правдивой информации о товарах, работах, услугах, реализуемых на российском рынке; формирование потребительской культуры у всех слоев населения; непрерывное потребительское образование, охватывающее все уровни системы образования учащихся.
}

Конфедерация обществ потребителей является членом международной организации «International Testing» («Международная экспертиза»), члены которой постоянно обмениваются результатами многих экспертиз. В процессе совместных межгосударственных экспертных разработок происходит сравнение товара, реализуемого в разных странах, в том числе производимого одной фирмой.

Необходимо указать и на законотворческую работу Конфедерации обществ потребителей, которая в 1995-1996годах приняла участие в разработке российского закона «О защите прав потребителей». Для своего времени данный документ являлся очень прогрессивным и одним из немногих реально действующих. По степени лояльности к потребителю наш закон можно смело поставить на второе место после аналогичного закона США. За прошедшие 20 лет миллионы потребителей смогли, опираясь на его нормы, отстоять свои права в споре с недобросовестными продавцами, исполнителями, изготовителями ${ }^{21}$.

Посредством этого закона реализуется весьма значимая общеправовая цель - достижения определенного уровня безопасности как населения, так и самого государства- России. Международные стандарты в этой сфере рекомендуют правительствам поощрять и обеспечивать наличие возможности для проверки и выдачи свидетельств о безопасности, качестве и технических характеристиках основных потребительских товаров и услуг ${ }^{22}$.

Значимым событием для темы настоящей статьи является то, что в марте 2012 года российская общественность праздновала 20-летие принятия Закона о защите прав потребителей. При этом очевидно, что, несмотря на сложность соблюдения всех его положений, Закон может быть назван как адаптированный к условиям

\footnotetext{
${ }^{21}$ Именно в 1996 году и был разработан и принят Закон о защите прав потребителей. Целью данного Закона является регулирование отношений, возникающих между потребителями и изготовителями, исполнителями, импортерами, продавцами при продаже товаров; определение прав потребителей на приобретение товаров(работ, услуг) надлежащего качества и безопасных для жизни, здоровья, имущества потребителей и окружающей среды; получение информации о товарах (работах, услугах) и об их изготовителях. Настоящий Закон обеспечивает государственную и общественную защиту интересов этих слоев общества.

${ }^{22}$ См.: п.26 Руководящих принципов для защиты прав потребителей ООН 1985г.
} 
рыночных отношений, отвечающий большинству требований международного права. Имеются и перспективы его совершенствования ${ }^{23}$. Важным является то, что государство не ослабляет контроль над всеми формами предпринимательской деятельности, связанной со сферами оказания услуг, торговли и другими.

По нашему мнению, следует также проводить целенаправленную политику по укреплению бизнеса, ведущегося отечественными производителями, с целью защиты не только прав потребителей, но и товаров, а также услуг ${ }^{24}$. В настоящее время «экономическая безопасность» является темой, которая вызывает интерес не только у юристов, но и у экономистов ${ }^{25}$, что требует привлечения самого широкого спектра знаний с целью определения оптимального пути решения проблем, связанных с защитой прав потребителей ${ }^{26}$. Товары, производимые в России, безусловно, проходят больший контроль на предмет качества и соблюдения норм безопасности. Дешевле и проще активизировать это направление отечественной экономики, чем проводить затратные в финансовом отношении контрольные проверки в отношении иностранной продукции ${ }^{27}$. Такие меры сэкономят не только национальные средства, остающиеся в государстве, но и позволят не допустить подачу жалоб в международные суды.

${ }^{23}$ См. подробнее: Богдан В.В. Положения Закона о защите прав потребителей о неустойке нуждается в совершенствовании /Гражданское право. 2011.№4.C.9-11.

${ }^{24}$ См. подробнее: Всегда ли полезны закупки зарубежных технологий?/Жилищно-коммунальное хозяйство (ЖКХ). 2012.№1-2. C.8.

${ }^{25}$ Керул А.-Ж., Ренуар А. Оценка права с точки зрения юридической безопасности / Журнал зарубежного законодательства и сравнительного правоведения. 2010.№6(25).С.4-18.

${ }^{26}$ См. подробнее: Общая теория безопасности /Актуальные методологические и социально-политические проблемы. М. 1994; Современные проблемы национально-государственной и международной безопасности. Сборник материалов конференции. М. 1992; Редкоус В.М. Административно-правовое обеспечение национальной безопасности в государствахучастниках СНГ/Автореферат д.ю.н. М., 2011; Flockhart T., Rees G. W. A Core Europe? The EU and the WEU/ Rethinking Security in Post- Cold War Europe. L., N. Y 1998. P.71.

${ }^{27}$ Например, проблемы проверки радиационной безопасности товаров(продуктов питания) на границе в пунктах таможенного досмотра являются особо актуальными для России / См.: Попов А.С. Угрозы пограничной безопасности России / Независимое военное обозрение. 1998..№.7.
Активный выход нашего государства в начале- середине 90-х годов ХХ века на мировую арену, усиление межгосударственной торговли в основном товарами народного потребления, привели к подписанию ряда международных соглашений России с другими странами и международными организациями в этой области. Например, в июле 2011 года был подписан Меморандум о сотрудничестве в области защиты прав потребителей между Федеральной службой по надзору в сфере защиты прав потребителей и благополучия человека и Ведомством справедливой конкуренции и защиты потребителей Монголии (The Authority for Fair Competition and Consumer Protection of Mongolia, AFCCP).

Для решения проблем, связанных с вступлением России и других стран Содружества Независимых Государств во Всемирную Торговую Организацию (ВТО), имеют большое значение рекомендации Международной Федерации потребительских организаций, в которых подчеркивается: «принимая во внимание интересы и нужды потребителей во всех странах, особенно в развивающихся, признавая, что потребители зачастую находятся в неравном положении с точки зрения экономических условий, уровня образования и покупательной способности, следует стремиться, что бы потребители имели право на доступ к безопасным товарам. Не менее важно содействовать справедливому, равноправному и устойчивому экономическому и социальному развитию всех государств» ${ }^{28}$.

Что же касается норм Всемирной Торговой Организации, применительно к защите прав человека, то участие в ВТО даёт России множество преимуществ. Их получение и является в прагматическом смысле целью присоединения к ВТО, которая отвечает за разработку и внедрение новых торговых соглашений, а также контролирует вопросы соблюдения членами организации всех соглашений, подписанных большинством стран мира и ратифицированных их парламентами.

Вступление России в ВТО потребует выполнения многих обязательств в сфере безопасности потребительских товаров. Ряд государственных органов контроля, и среди них в первую очередь,

\footnotetext{
${ }^{28}$ См.: Резолюцию Генеральной ассамблеи ООН № 39/248 от 9 апреля 1985 г., закрепившую указанных 8 принципов прав потребителей.
} 
Федеральная служба по надзору в сфере защиты прав потребителей и благополучия человека (Роспотребнадзор), принимают ряд мер, чтобы ввозимая в Россию продукция соответствовала международным стандартам. К этому побуждают международные обязательства, взятые Россией, в связи с ее членством в таких международных организациях как ВО3, МОТ и иных. Например, в мае 2008 года вступил в силу Федеральный закон № 51-Ф3 «О присоединении Российской Федерации к Рамочной конвенции ВОЗ по борьбе против табака», принятой на 56 сессии Всемирной ассамблеи здравоохранения в Женеве в мае 2003 года. Требования, установленные указанным международным договором (сторонами которого на сентябрь 2008 года являются более 160 стран), стали обязательны для Российской Федерации ${ }^{29}$.

В целях обеспечения дальнейшего осуществления работ по подготовке к присоединению Российской Федерации к Всемирной торговой организации (ВТО) и выполнению требований соглашений ВТО по применению санитарных и фитосанитарных мер (СФС) и техническим барьерам в торговле (ТБТ) в области санитарно-эпидемиологической безопасности Роспотребнадзор проводил постоянный мониторинг, а также обеспечивал необходимой информацией государственные органы и общественность ${ }^{30}$. Например, 20 апреля 2012года Руководитель Роспотребнадзора Г.Г. Онищенко и Генеральный директор Генерального директората Европейской комиссии по здравоохранению и защите потребителей (DG SANCO) П.Т. Коджи обсудили вопросы, связанные с мерами, применяемыми в Европейском союзе относительно товаров, импортируемых из Японии, где в марте 2011 года в результате сильного землетрясения произошла авария на АЭС Фукусима- $-^{31}$.Следует указать, что никакие меры не могут считаться чрезмерными в случае, когда возникает вопрос о безопасном использова-

\footnotetext{
${ }^{29}$ Среди обязательств, установленных Женевской конвенцией по борьбе против табака, содержится следующее: государства - стороны договора должны защищать свою политику от воздействия коммерческих и других корпоративных интересов табачной промышленности в соответствии с национальным законодательством. Таким образом, отдается предпочтение национальному законодательству.

${ }^{30}$ См.: Приказ Роспотребнадзора №16 от 24.01.2008/ сайт: http://www.rospotrebnadzor.ru.

${ }^{31}$ См.: www.rospotrebnadzor.ru
}

нии товаров народного потребления, лекарств или оказания услуг в жизненно необходимых сферах.

Отмечая значимость активизации сотрудничества государств в экономической сфере в евразийском регионе, следует отметить, что во всех странах Содружества Независимых Государств существуют и реально применяются специальные законы о защите прав потребителей. Развитие национальных систем защиты прав потребителей в государствах - участниках СНГ требует учитывать реалии в экономике и политике, угрозы войн и миграционные перемещения. Во всех законодательных актах государств - участников СНГ предусматривается ответственность государства за потребительскую политику. Однако есть некоторые различия административно-правового характера. В одних странах - какой-либо конкретный орган не наделяется специальными полномочиями, а функции по защите прав потребителей должны реализовывать все государственные органы, связанные с качеством и безопасностью продукции, в пределах своей компетенции (Республика Армения, Республика Казахстан, Азербайджанская Республика, Республика Молдова). В других странах определен конкретный орган, ответственный за потребительскую политику (Республика Беларусь, Кыргызская Республика, Республика Узбекистан, Российская Федерация, Республика Таджикистан, Украина). В ряде стран - закон предусматривает право органов местного самоуправления создавать специальные структуры для защиты интересов потребителей и наделять их полномочиями (Азербайджанская Республика, Кыргызская Республика, Российская Федерация, Республика Таджикистан, Республика Узбекистан, Украина), в других - это положение отсутствует.

Импульсом для сближения потребительского законодательства государств - участников СНГ стало принятие в 1995 году Межпарламентской Ассамблеей СНГ Модельного закона «О защите прав потребителей». Положения этого документа учитывались почти во всех государствах.

Среди первых международно-правовых актов СНГ на предмет защиты прав потребителей следует назвать Соглашение об основных направлениях сотрудничества государств - участников Содружества Независимых Государств в области защиты прав потребителей от 19 мая 2011 года. Отмечается, что целью настоящего Соглашения 
является «создание правовых и организационных основ сотрудничества Сторон по проведению согласованной политики в области защиты прав потребителей, направленной на формирование равных условий для граждан государств - участников Содружества по защите их интересов от недобросовестной деятельности хозяйствующих субъектов, действующих на территориях государств - участников настоящего Соглашения»(ст.2). Характерной особенностью данного соглашения является то, что на первом месте с учетом реального положения дел в социальных сферах государств СНГ, выделены нормы национального права, нормы международного права - на втором. Основным достижением данного соглашения стало провозглашение нового межгосударственного института- Консультативного совета по защите прав потребителей государств - участников СНГ.

В целях реализации Решения Совета глав правительств СНГ от 19 мая 2011 года о создании органа отраслевого сотрудничества СНГ в области защиты прав потребителей 24 ноября 2011 года в Федеральной службе по надзору в сфере защиты прав потребителей и благополучия человека (Роспотребнадзоре) состоялось первое заседание Консультативного совета по защите прав потребителей государств - участников СНГ, в котором приняли участие члены Совета, представляющие Республику Армения, Республику Беларусь, Республику Казахстан, Кыргызскую Республику, Республику Молдова, Российскую Федерацию, Республику Таджикистан и Украину, а также представители Исполнительного комитета СНГ и Федеральной Антимонопольной Службы России.

В завершение следует отметить, что процесс активного вхождения России в международно-правовое поле требует повысить уровень безопасности ведения бизнеса в нашем государстве в сочетании с адекватной защищенностью самого человека-потребителя путем создания ряда гарантий как административного порядка, так и обеспечивая уверенность в будущем последующему поколению российских граждан. Повышение значимости международного права в формировании правовой политики обязывает законодателей изучать зарубежные аналоги ${ }^{32}$. Для России,

${ }^{32}$ См.: Чельшев М.Ю. Вопросы межотраслевых связей гражданского права в Концепции развития гражданского законодательства и проекте ГК РФ/ Гражданское право. 2011.№1.С.3. прежде всего, необходимо учесть опыт развитых европейских стран, проводящих взвешенную социальную политику, направленную на удержание достаточно высокого уровня жизни населения Европейского союза в начале XXI века. Не последнюю роль в будущем стабильном существовании России имеет и проблема гармонизации законодательства в пределах такого регионального объединения как Содружество Независимых Государств.

Еще одной из проблем российской действительности, усложняющей решение многих задач, связанных с защитой прав человека в социальной сфере, является миграция населения из республик Центральной Азии, Закавказья, Украины, Молдовы.

Необходимо лоббирование экономических и политических проектов, обусловленных защитой национальных интересов России на международном уровне с целью избежания миграционного потока из стран СНГ, угрожающих национальной безопасности страны ${ }^{33}$. Одним из первоочередных средств может быть усиление сотрудничества государств СНГ в социальной сфере, в том числе и защита прав потребителей. Как известно, товары, услуги и люди могут перемещаются и без санкций государства, но только скоординированная политика государств Содружества может стать препятствием на пути к эскалации социальной и политической напряженности в соседних государствах.

Правильность курса государства, имеющего целью усиление контроля, служат положения Руководящих принципов ООН для защиты интересов потребителей 1985 года, где указывается: «Правительства должны самостоятельно разрабатывать, укреплять или продолжать активную политику защиты интересов потребителей с учетом изложенных ниже руководящих принципов. При этом каждое правительство должно определить свои собственные первоочередные задачи в области защиты интересов потребителей в соответствии с экономическими и социальными условиями страны и потребностями своего населения, а также с учетом издержек и преимуществ намечаемых мер».

Международной Федерацией потребительских организаций (CI) был определен девиз Всемирного

\footnotetext{
${ }^{33}$ См. подробнее: Смирнова Е.С. Проблемы правового статуса иностранцев в условиях глобализации. Тверь. 2012.
} 
дня защиты прав потребителей на 2012 год: «Our money, our rights: campaigning for real choice in financial services» («Наши деньги, наши права: кампании за правильный выбор на рынке финансовых услуг»). Именно в таком аспекте должны действовать как законодатели, так и исполнители нормативно-правовых актов государства в целях достижения населением достойного уровня социальной защищенности применительно к их потребительским целям. Учитывая современные социально - экономические тенденции, дикту- ющие новые ответственные задачи, следует помнить, что только совместными действиями государства и общества при одновременной социальной ответственности бизнеса может быть сформирована доступная и эффективная система защиты прав потребителей, являющаяся одним из основных элементов общенациональной стратегии повышения уровня жизни населения. Межгосударственное сотрудничество в этом случае станет необходимым дополнением эффективной работе национальных органов России.

\section{Библиография:}

1. Богдан В.В. Положения Закона о защите прав потребителей о неустойке нуждается в совершенствовании /Гражданское право. 2011.№4.С.9-11.

2. Вавилин Е.В., Челышев М.Ю. О концепции гражданско-правовой политики /Гражданское право. 2012. №1.C.14.

3. Керул А.-Ж., Ренуар А. Оценка права с точки зрения юридической безопасности / Журнал зарубежного законодательства и сравнительного правоведения. 2010.№6(25).С.4-18.

4. Лукашук И.И. Международное право. Общая часть. Учебник. М., 1996. С.64.

5. Медведев Д.А. Новый Гражданский Кодекс РФ: вопросы кодификации /Кодификация российского частного права. Под.ред. Д.А. Медведева. М., 2008.

6. Смирнова Е.С. Проблемы правового статуса иностранцев в условиях глобализации. Тверь. 2012.

7. Charolles V. Le capitalism est-il liberal ? /Debat. P.2010. N.161. P.88-103.

8. Demeulemeester J. L., Diebolt Cl. Renouveler la science economique neo -classique ?Prendre lhistorisite au serieux/Assotiation francaise de cliometrie Worcing papers. 2011. N.3 P.15.

9. Flockhart T., Rees G. W. A Core Europe? The EU and the WEU/ Rethinking Security in Post- Cold War Europe. L., N. Y 1998. P.71.

10. Hugon Ph. Apres la crice, un nouveau paradigm du development/Problems econ. P. 2011. №3011. P.46.

11. Keirse A.L.M. European impact on contract law A perspective on the interlinked contributions of legal scholars. Legislators and courts to the Europeanization of counteract law /Utrecht law rev. Utrecht. 2011.V.7.N.1.P.46.

12. King M. Do we need an international monetary system?/Mode of access : http / www. Centpapiers. Com. $1 \%$ E2\% 80\% 36275.

13. Wagner G. Functions and principles in light of the proposal for a directive on consumer right / Erasmus law rev. Rotterdam 2010. V.3. N.1.,P.47-70.

\section{References (transliteration):}

1. Bogdan V.V. Polozhenija Zakona o zashhite prav potrebitelej o neustojke nuzhdaetsja v sovershenstvovanii /Grazhdanskoe pravo. 2011.№4.S.9-11.

2. Vavilin E.V., Chelyshev M.Ju. O koncepcii grazhdansko-pravovoj politiki /Grazhdanskoe pravo. 2012. №1.S.14.

3. Kerul A.-Zh., Renuar A. Ocenka prava s tochki zrenija juridicheskoj bezopasnosti / Zhurnal zarubezhnogo zakonodatel'stva i sravnitel'nogo pravovedenija. 2010.№6(25).S.4-18.

4. Lukashuk I.I. Mezhdunarodnoe pravo. Obshhaja chast'. Uchebnik. M., 1996. S.64. 
5. Medvedev D.A. Novyj Grazhdanskij Kodeks RF: voprosy kodifikacii /Kodifikacija rossijskogo chastnogo prava. Pod.red. D.A. Medvedeva. M., 2008.

6. Smirnova E.S. Problemy pravovogo statusa inostrancev v uslovijah globalizacii. Tver'. 2012.

7. Charolles V. Le capitalism est-il liberal ? /Debat. P.2010. N.161. P.88-103.

8. Demeulemeester J. L., Diebolt Cl. Renouveler la science economique neo-classique ?Prendre lhistorisite au serieux/Assotiation francaise de cliometrie Worcing papers. 2011. N.3 P.15.

9. Flockhart T., Rees G. W. A Core Europe? The EU and the WEU/ Rethinking Security in Post- Cold War Europe. L., N. Y 1998. R.71.

10. Hugon Ph. Apres la crice, un nouveau paradigm du development /Problems econ. P. 2011. №3011. P.46.

11. Keirse A.L.M. European impact on contract law A perspective on the interlinked contributions of legal scholars. Legislators and courts to the Europeanization of counteract law /Utrecht law rev. Utrecht. 2011.V.7.N.1.R.46.

12. King M. Do we need an international monetary system?/Mode of access : http / www. Centpapiers. Com. $1 \% \mathrm{E} 2 \% 80 \% 36275$.

13. Wagner G. Functions and principles in light of the proposal for a directive on consumer right / Erasmus law rev. Rotterdam 2010. V.3. N.1.,P.47-70. 